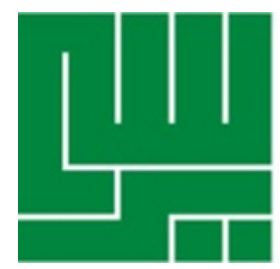

\title{
Perilaku Penyalahgunaan Obat Pada Komunitas Lesbian Di Kota Makassar
}

\author{
Drugs Addict Behavior in Lesbian Community in Makassar City
}

\author{
Indra Fajarwati Ibnu ${ }^{1}$, Muh.Syafar ${ }^{1}$, A.Amalia Arismaya ${ }^{1}$ \\ Departemen Promosi Kesehatan FKM Unhas, Departemen Promosi Kesehatan FKM Unhas, \\ Departemen Promosi Kesehatan FKM Unhas \\ Email: indra5462@gmail.com
}

\section{KATA KUNCI Penyalahgunaaan Obat, Lesbian}

\section{KEYWORDS Drug Abuse, Lesbian}

ABSTRAK Lesbian merupakan salah satu kelompok yang mempunyai resiko tinggi menjadi seorang penyalahguna obat karena faktor pergaulan, trauma, konflik dan lingkungan. Penyalahgunaan obat pada komunitas lesbi terjadi karena kurang tersentuhnya komunitas tersebut sehingga seorang lesbi dapat menjadi pengguna obat-obatan karena dipengaruhi oleh perilaku pada masing-masing pergaulan dikomunitas lesbi. Penelitian ini bertujuan untuk memperoleh informasi mengenai perilaku lesbian terhadap penyalahgunaan obat. Penelitian ini adalah penelitian kualitatif dengan pendekatan studi kasus. Informan dalam penelitian adalah lesbian yang terdiri dari terdiri dari 2 butchi (peran sebagai pria) dan 1 informan femm (peran sebagai wanita). Pengumpulan data primer dilakukan melalui teknik wawancara mendalam dan observasi. Hasil penelitian menunjukkan bahwa informan mulai menjadi lesbi sejak SD, SMP dan SMA dengan alasan ketertarikan sendiri yang sudah ada dalam diri dan karena pengaruh dari teman. Semua lesbi menggunakan obat dalam pergaulan di komunitas lesbinya. Jenis obat yang digunakan oleh lesbi yaitu somadril dan karnopen. Lesbi menggunakan obat dengan alasan untuk menghilangkan stress, membuat tenang, simbol sebagai anak gaul dan untuk melakukan seks. Untuk melakukan hubungan seksual dengan pasangannya, disamping minum obat tersebut, lesbi juga menggunakan vinger dan vibrator. Berdasarkan hasil penelitian maka disimpulkan bahwa perilaku lesbi sudah muncul sejak usia anak-anak hingga remaja. Perilaku ini kadang tidak sadari munculnya dengan berbagai alasan hingga lesbi terjebak dalam status yang membuat komunitas tersendiri demi pemuasan psikologi dan seksualnya. Perilaku berisiko yang dilakukan pun sering menyertai pergaulan lesbi seperti menggunakan obat penenang yang dapat mereka dapatkan diapotik untuk mengatasi stress dan melakukan seks. Hubungan seks dilakukan dengan pasangan lesbinya maupun dengan tante-tante bahkan kadang dengan teman lesbi apabila lesbi telah teler. Disarankan kepada Balai Pengawasan Obat dan Makanan untuk memperketat pengawasan terhadap pembelian obat-obat penenang di apotik-apotik. 
ABSTRACT Lesbian is one of the high risk group that could be involved in drug abuse because of social, trauma, conflict, and environmental factors. Drug abuse in lesbians community happened because they have less attention, so that an lesbian can be a drug abuser because of the behavioral influence in that community. This research has an object to get more information about lesbians' act to drug abuse. This is a qualitative research with case study method that has been done by doing exclusive interview, observation, and participating approach. The informans in this research are 2 butchi (as a male) and 1 femm (as a female). Result of the research show that informan has become a lesbian since elementary school, junior, and senior high school because of having an interest in themselves and being influenced by their friends. Kind of drugs that are used in lesbian are somadril and karnopen. Lesbian use this drug to reduce their stress, make them calm, be known as a punk, and make sex. Effect of these drugs are can make people 'fly', addicted, and become light in weight. Way that can be used to make a faster react of these drugs is consume it with drinking soda, tea, mineral water, and eating hot meals. The lesbian community is very closed off in society because lesbian community hasn't been accepted in society. Lesbians use vinger and vibrator in doing sex. Lesbians are able to have sex with their couple and friends if they have been drunk. Amount of drugs that is usually being used is $3-12$ tablets. After using the drug will muttu lesbians, doing things that are unimportant, and swaying while listening to music. They get information of the drug from their friends and buy in pharmacy. Lesbian usually have a conflict with their parents in the begining, but finally their parents lose their attention to their child and accept them as a lesbian. Result of this research suggest for Health Department to make an education in lesbian community about drug abuse. Beside that, suggesting the government to watch out of buying psychotropic and narcotic drugs in pharmacy. And the importance of parents to become a soulmate for their child, know their friends and social community of their child, so that their child could be in parents' control and their religion science is improved then they will not involved in drug abuse.

\section{PENDAHULUAN}

Penyalahgunaan dan peredaran gelap narkotika hingga saat ini masih merupakan permasalahan dunia yang cukup serius. Berdasarkan World Drug Report pada tahun 2008 jumlah penyalahgunaan narkoba di dunia diperkirakan berjumlah antara 155-250 juta orang (3,5-5,7\% penduduk usia 15-64 tahun) 15,9 juta diantaranya adalah pengguna napza injeksi dan 3 juta diantaranya hidup dengan HIV. Secara global jumlah penyalahgunaan ganja berkisar antara 129-190 juta orang, penyalahgunaan Amphetamine-Type Stimulants (ATS) berkisar antara 13,7-52,9 juta orang, penyalahgunaan kokain berkisar antara 15-19 juta orang, penyalahgunaan opiat berkisar antara 12,8 21,8 juta orang, penyalahgunaan heroin tercatat sebanyak 11,3 juta orang (UNODC, 2010)

Di Propinsi Sulawesi Selatan, diperkirakan 300 orang pecandu napza yang terdeteksi sedangkan yang tidak terdeteksi bisa jauh lebih banyak dari angka tersebut. Hasil RAR juga menunjukkan bahwa yang menjadi trend yang diminati oleh banyak remaja adalah penggunaan narkoba suntik/putauw. Selain itu ada 1.500 orang waria, pasangan sesama jenis laki-laki (gay) maupun perempuan (lesbian) sebanyak 500 orang 
dan pengguna jarum suntik sebanyak 3.692 orang serta pasangan pengguna jarum suntik sebanyak 3.692 orang (Ilyas, 2008). Bahaya yang dapat ditimbulkan pada lesbi maupun gay yaitu ketergantungan obat dan HIV dan AIDS karena penggunaan jarum suntik yang dilakukan secara bergantigantian. Akan tetapi dalam lesbian terjangkit virus HIV dan AIDS memiliki sedikit kemungkinan jika dibandingkan dengan kaum gay yang lebih besar resikonya. Selain terjangkit HIV dan AIDS penyalahgunaan obat (napza) dapat berdampak pada kematian karena over dosis diakibatkan penggunaan napza (obatobatan) secara belebih. Pada wanita-wanita lesbian, total jumlah pasangan seks lebih rendah, namun tetap di atas rata-rata jika dibandingkan wanita heteroseksual. Banyak wanita lesbian juga berhubungan seks dengan pria. Wanita lesbian 4 kali lebih memungkinkan untuk mempunyai lebih dari 50 pasangan pria sepanjang hidupnya dibandingkan wanita heteroseksual. Sehingga ada kemungkinan lesbian dapat terjangkit HIV dan AIDS. (Fethers ,2000)

$\begin{array}{ccc}\text { Rosario dalam } & \text { Meininger } & \text { (2002) } \\ \text { melaporkan } & \text { pada tahun } & \text { 1997, }\end{array}$
penyalahgunaan obat-obatan 0,4 kali lebih tinggi pada kaum lesbian atau biseksual dibanding kaum heteroseksual dan 4,4 kali lebih tinggi pada gay atau laki-laki biseksual dari pada kaum heteroseksual. Hal ini memiliki korelasi positif antara penyalahgunaan obat-obatan dengan adanya tekanan psikologis pada kaum Gay, Lesbi, dan Biseksual (GLB). Lesbian sangat rentan mengonsumsi narkoba. Awalnya, tentu saja hanya untuk berfantasi dan mencari sensasi. Itu biasa dilakukan agar mengundang gairah bagi para lesbian lainnya. Ini berbeda dari kasus perempuan tomboi yang hanya sekadar ingin tampil layaknya laki-laki. Dibanding laki-laki homoseks (gay), lesbian cenderung lebih tertutup. Mereka berhati-hati mengungkapkan jati diri di hadapan publik. Akibatnya, lesbian kurang begitu dikenal dan dipahami dibanding laki-laki homoseks. Selain itu, alasan seksisme, lesbian yang sudah terdiskriminasi karena jenis kelamin, makin tersingkir akibat orientasi seksual.

Oleh karena tekanan dan stigma pada orientasi seksualnya mengakibatkan terbatasnya keterampilan dan sumber pendapatan, menyebabkan ketergantungan pada alkohol dan obat-obatan terlarang. (Muctaromah, 2010)

Berdasarkan permasalahan di atas maka si peneliti tertarik untuk menganalisis lebih lanjut tentang perilaku lesbi terhadap penyalahgunaan obat di Kota Makassar.

\section{METODE PENELITIAN}

\section{Jenis Penelitian}

Instrumen Penelitian Jenis penelitian yang akan digunakan adalah kualitatif dengan desain studi kasus.

\section{Lokasi Penelitian}

Penelitian ini dilaksanakan di kota Makassar.

\section{Informan Penelitian}

Informan dalam penelitian ini adalah lesbi yang ada di Kota Makassar dan tergabung dalam suatu komunitas. Informan diperoleh melalui informan kunci yang merupakan salah satu lesbi yang secara terus terbuka mengakui identitas dirinya sebagi lesbi pada peneliti.

\section{Metode Pengumpulan Data}

Data ini diperoleh melalui wawancara mendalam (Indepth Interview) dan obsevasi. Untuk wawancara mendalam menggunakan pedoman wawancara dengan berdasarkan pada teori perilaku dari Lawrence Green (1980), bahwa perilaku dipengaruhi oleh 3 faktor utama yakni :

a. Faktor predisposisi (predisposing faktor).

Faktor-faktor ini mencakup pengetahuan dan sikap masyarakat terhadap kesehatan, tradisi dan 
kepercayaan masyarakat terhadap halhal yang berkaitan dengan kesehatan, sistem nilai yang dianut masyarakat, tingkat pendidikan, tingkat sosial ekonomi dan sebagainya.

b. Faktor pemungkin (enabling faktor) Faktor-faktor ini mencakup ketersediaan sarana dan prasarana atau fasilitas kesehatan bagi masyarakat.

c. Faktor penguat (reinforcing faktor) Faktor-faktor ini meliputi faktor sikap dan perilaku tokoh masyarakat, tokoh agama dan perilaku petugas termasuk petugas kesehatan, orang tua yang dapat menjadi faktor penyalahgunaan obat. Seperti status orang tua sehingga seseorang dapat menyalahgunaan obat.

Untuk wawancara mendalam menggunakan alat bantu seperti tape recorder. Wawancara mendalam dilakukan berulang kali pada setiap informan dibeberapa tempat yaitu kost informan dan tempat nonkrong informan. Saat wawancara mendalam dilakukan pula observasi terhadap perilaku informan menggunakan lembar observasi.

\section{Pengolahan dan Penyajian Data}

Pengolahan data dilakukan dengan analisis isi (content analysis).

\section{HASIL PENELITIAN DAN DISKUSI}

\section{Karakteristik Informan}

Informan yang kesemuanya adalah lesbi, berjumlah 3 orang dan dua diantaranya merupakan pasangan lesbi. Adapun umur informan terdiri dari 19 tahun, 24 tahun dan 28 tahun. Pendidikan informan semuanya tamat SMA. Pekerjaan informan semuanya merupakan mahasiswa di salah satu perguruan tinggi negeri dan swasta di Makassar. Peran informan dalam lesbi antara lain informan pertama adalah seorang butchi (sebagai pria), informan kedua butchi (sebagai pria) dan informan ketiga adalah seorang femm (sebagai wanita). Seorang lesbi dalam hasil penelitian ini, telah menjadi lesbi mulai dari SD, mulai dari SMP dan mulai dari
SMA. Informan masing-masing berumur 19 tahun, 24 tahun dan 28 tahun. Informan pada awal menjadi seorang lesbi ada yang merasa aneh akan dirinya sendiri dan merasa ada sesuatu yang lain dalam dirinya karena merasa tertarik dengan wanita yang cantik atau yang seksi-seksi. Mereka menjadi seorang lesbi karena beberapa alasan antara lain yaitu karena ketertarikan sendiri dan juga karena dipengaruhi oleh teman yang menjadi pasangannya.

Banyak perempuan beranggapan bahwa mereka menjadi lesbi sejak lahir, sedangkan yang lainnya beranggapan bahwa itu merupakan suatu pilihan dalam kehidupannya. Lesbianisme juga didefenisikan bukanlah sekedar faktor alamiah, tetapi lebih kepada masalah prefensi seksual berdasarkan pengalaman perempuan yang tidak terjadi pada suatu titik spesifik dalam hidup seseorang perempuan. Itu bisa terjadi setiap saat, ketika beranjak remaja, dewasa, saat menjadi orang tua, ataupun di masa tua. Lesbi tidak mengenal kelas sosial, ia bisa siapa saja, guru, perawat, model, aktris, agamawan, dan lain-lain. Bagaimana seseorang itu menjadi lesbi, merupakan suatu misteri kehidupan. Argumen yang dilihat dari sudut pandang "Alami" (seorang menjadi lesbi sejak lahir) bertolak belakang jika dilihat dari sudut pandang "Kejadian yang bukan alami"(adanya suatu kejadian yang membua kita menjadi lesbi). (Agustina, 2005,p.18-20)

Dalam kehidupan lesbi mereka juga mempunyai komunitas. Komunitas tersebut dibentuk untuk membahas tentang perkembangan lesbi dalam masyarakat yang tidak ingin diketahui dalam masyarakat. Komunitas tersebut ada yang menjaring atau merekrut anggota baru dengan kata lain mereka mempengaruhi seseorang agar bisa menjadi lesbi. Komunitas lesbi memiliki tempat untuk berkumpul dan itu bukan hanya satu tempat tetapi ada beberapa tempat yaitu: depan Benteng Roterdam cafe taman, popsa, dan juga di KDS (KFC Dua Satu yang ada di Jalan Ratulangi). Akan tetapi 
mereka berkumpul pada hari-hari tertentu. Komunitas lesbi sangat tertutup dalam masyarakat karena masyarakat belum bisa menerima keadaan seorang lesbi dalam lingkungan masyarakat. Tetapi saat ini komunitas lesbi mulai terlihat karena adanya anak lesbi yang masih kacupingkacuping atau anak baru gede (ABG), kacuping-kacuping tersebut memperlihat secara terang-terangan pada masyarakat sehingga dalam komunitas terbagi dua antara yang umurnya sudah dewasa masih sangat tertutup dalam masyarakat dan yang masih kacuping-kacuping telah terangterangan di tempat umum memperlihatkan kehidupan komunitas lesbi.

Gaya berpacaran lesbi seperti pasangan selayak pria dan wanita yang jatuh cinta akan tetapi yang menjadi perbedaan jika melakukan hubungan seks karena mereka berhubungan seks dengan menggunakan tangan atau biasa di dalam istilah menggunakan vinger (jari tangan) yang digunakan sebagai pengganti penis. Penggunaan jari tangan dapat menyebabkan terjadinya lecet pada alat kelamin tetapi dari keseluruhan menganggap bahwa menggunakan jari tangan itu bersih karena tidak terjadi sesuatu dan jika ingin melakukan hubungan badan mereka akan mencuci tangan mereka dengan sabun dan memotong kuku yang sudah panjang Selain vinger (jari tangan) mereka menggunakan vibrator untuk dijadikan pengganti penis. Vibrator tersebut biasanya dapat diperoleh dari suatu yayasan atau LSM. Vibrator tersebut jarang digunakan oleh lesbi kecuali jika mereka berhubungan seks dengan tantetante. Seorang lesbi yang berperan sebagai pria butchi akan puas jika pasangannya sudah merasa puas. Seorang lesbi akan melakukan masturbasi jika lesbi tidak mempunyai pasangan dan saat itu dia merasa horny. Ada juga yang melakukan dengan teman atau juga pacar dari pasangannya karena mereka sudah teler atau sudah tidak sadar. Dalam komunitas lesbi bisa terjadi banyak kejadian yaitu mereka bisa saja menjadi normal dan mempunyai suami dan berubah peran dari seorang butchi (berperan pria) menjadi femm (berperan wanita) bergitupun sebaliknya karena adanya trauma pada pasangan dan juga laki-laki. Seorang lesbi terkadang melakukan suatu perjanjian dengan seseorang untuk menjadi lesbi akan tetapi tetap berhubungan dengan pasangan lesbinya karena hanya ingin menutupi bahwa dirinya bukan seorang lesbi karena sudah mempunyai seorang suami.

\section{Pemahaman Terhadap Penyalahgunaan Obat}

Seorang lesbi mengetahui bahwa jenis obat yang digunakan karena adanya pengetahuan yang dimiliki dan juga karena pernahnya merasakan obat dengan menggunakan obat tersebut. Pemahaman yang diungkapakan akan jenis obat yang digunakan oleh lesbi yang yaitu Somadril dan Karnopen. Somadril adalah obat untuk merileksasikan otot, anti nyeri, terutama pada otot karena trauma atau terkilir. dan dapat menurunkan ketidaknyamanan yang disebabkan oleh hal di atas. Karnopen merupakan obat keras yang mirip dengan obat somadril.

Dari hasil penelitian lesbi menggunakan obat karena dengan alasan untuk menenangkan diri dari suatu masalah, dengan mengkomsumsi obat menghilangkan stress atau dapat menenangkan diri, untuk dijadikan sebagai keren-kerenan sebagai simbol bahwa dia merupakan anak gaul. National Institute on Drug Abuse (2002) berhasil mengidentifikasi sejumlah faktor risiko memperbesar kemungkinan seseorang menyalahgunakan obat antara lain presepsi bahwa penggunaan obat dikeluarga, pekerjaan, teman dan sekolah adalah hal yang dapat diterima.

Dalam hasil penelitian yang dilakukan efek yang lesbi rasakan saat menggunakan obat yaitu fly (merasa badan terasa ringan), membuat stress hilang juga dapat melakukan sesuatu sesuai dengan keinginan mereka. Terkadang juga akan 
terbawa oleh perasaan yang dirasakan saat mengkomsumsi obat, lesbi akan marah jika ingin marah tergantung dari suasana hati yang dia punya.

Lesbi menggunakan obat dengan cara meminumnya bersama dengan Sprite atau Coca Cola, teh dan makan makananan yang pedas. Selain itu ada juga pantangan yang harus dihindari saat menggunakan obat yaitu tidak boleh memakan keju dan coklat. Jika memakan makanan tersebut yang menggunakan obat akan drop (tertidur) karena efeknya hanya sebentar saat menggunakan obat. Somadril diminum dengan mencampurnya dengan minuman keras agar bisa mabuk-mabukan. Selain minuman keras, minuman suplemen juga dicampur dengan obat

\section{Tindakan Terhadap Penyalagunaan Obat}

Banyaknya obat yang digunakan dalam satu kali pemakaian antara tiga sampai dua belas biji. Penggunaan untuk mendapatkan efek yang diinginkan baik dengan cara meminumnya secara sekaligus tetapi ada juga yang meminumnya hanya tiga biji kemudian diberi jedah waktu dan jika efek dari obat tersebut akan hilang maka obat yang dikomsumsi akan lebih banyak dari sebelumnya.Sekitar $15 \%$ pengguna narkoba mengawali petualangannya dengan menenggak obatobatan yang lumrah disimpan di lemari obat (hasil penelitian Asian Harm Reduction Network, AHRN, Indonesia). Salah satunya yang sangat populer ialah obat tidur. Obat yang dalam bahasa gaul disebut boti itu memang idola buat para pemula. Biasanya diresepkan oleh dokter buat pasien yang punya masalah sulit tidur. Yang paling sering diresepkan yaitu golongan benzodia-zepin dan barbiturat. Umumnya, obat-obat itu punya efek mempengaruhi sistem saraf pusat di otak.

Hasil penelitian ini menunjukkan bahwa setelah menggunakan obat mereka lesbi akan melakukan sesuatu sesuai dengan yang mereka inginkan. Bila mempunyai pasangan lesbi tersebut akan melakukan hubungan seks dan jika hanya sendiri dia akan fly atau berfantasi dan mendengarkan suara musik dan menikmati suara musik tersebut sambil bergoyanggoyang. Tetapi ada juga lesbi yang setelah mengkomsumsi dan jika berkumpul bersama dengan teman-temannya maka mereka akan melakukan hal-hal bodoh yang atau bercerita sesuatu hal yang bodoh. Hasil penelitian Torres dan Horowitz (1996) menunjukkan bahwa (a) ethanol dan kokain merupakan obat yang disalahgunakan yang dapat menghasilkan perubahan perilaku yang bertahan dalam waktu yang lama, termsuk ketergantungan; (b) suatu set jalur-jalur kecil (Patways) syaraf nampak merupakan perantara aksi zat adiktif dari ethanol dan kokain; (c) beberapa aspek menonjol dari ketergantungan obat dapat pula merupakan hasil perubahan dalam sinyal-sinyal intraseluler sebagaimana pola-pola spesifik dari ekspresi.

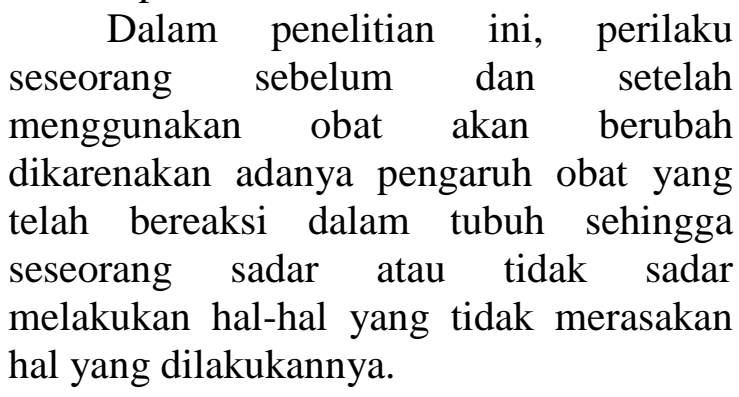

\section{Sumber Informasi Penyalahgunaan Obat}

Dalam penelitian ini didapatkan bahwa mereka mendapatkan informasi dari teman dan pasangan untuk memperoleh obat. Teman yang memberi informasi merupakan teman yang menawarkan obat pertama kali pada subyek tersebut. Pasangan yang memberikan informasi tentang obat yang digunakan adalah pasangan merupakan lesbi yang sudah lama mengkomsumsi obat tersebut sehingga dapat mengetahui tempat untuk mendapatkan obat tersebut dan akan diberitahukan pada pasangannya bahkan terkadang mereka pergi bersama-sama untuk membeli obat tersebut. 
Dari hasil penelitian, lesbi mendapatkan obat dari apotik yang dapat dijangkau akan tetapi apoteker yang menjual obat tersebut tidak menjualnya pada orang yang tidak dikenal sehingga untuk mendapatkan obat tersebut maka seorang lesbi yang telah kenal terlebih dahulu dengan apoteker akan memperkenalkan pada pasangan atau juga temannya agar apoteker tersebut mengenali wajahnya dan jika orang tersebut yang memberli obat maka akan diberi. Apoteker dan subyek harus waspada karena dapat ditangkap oleh polisi jika seorang polisi menyamar menjadi pembeli maka ia akan ditangkap jika menjualnya pada orang. Menurut penelitian Puslitban Farmasi (1992), asal obat yang disalahgunakan persentase terbesar dari kelompok (gang) dansebagian kecil dari memalsu resep/membeli di apotek.

\section{Hubungan Dengan Orang Tua}

Kepedulian orang tua dalam kehidupan lesbi mempunyai peranan penting karena mereka sudah diketahui bahwa seorang lesbi tetapi terjadi konflik yang mengakibatkan lesbi tersebut menggunakan obat karena konflik tersebut. Selain itu ada juga orang tua yang acuh tak acuh pada anaknya walaupun orang tuanya tahu bahwa anaknya menggunakan obat dan seorang lesbi. Orang tuanya tidak melarang ataupun memberi penjelasan atau pengarahan pada anak melainkan tidak peduli dengan apa yang terjadi pada anaknya dan menerimanya dengan ikhlas. Menurut National Institute on Drug Abuse (2002) , Beberapa studi melaporkan bahwa faktor-faktor sosial seperti keluarga inti, teman sebaya dan lingkungan pergaulan mempengaruhi perilaku remaja terhadap penyalahgunaan obat.

Dalam penelitian lesbi dan orang tuanya memiliki komunikasi yang lancar akan tetapi bias terjadi konflik-konflik yang membuat hubungan antara anak dan orang tua rengang. Ini akibat komunikasi yang tidak efektif yang dilakukan oleh orang tua. Baik tidaknya komunikasi antara orang tua dengan anak dipengaruhi oleh cara pandang atau persepsi anak terhadap komunikasi itu sendiri. Adanya perhatian tersebut dapat menyebabkan rasa kepedulian yang tinggi apabila salah satu pihak mengalami permasalahan, terutama pada remaja yang mudah terpengaruh oleh kehidupan atau lingkungan pergaulan yang buruk, misalnya penyalahgunaan narkoba. Hal ini karena penyalahgunaan narkoba salah satunya disebabkan oleh kesibukan orang tua dan hubungan interpersonal dalam keluarga (Hawari, 2000).

\section{SIMPULAN}

Awal seseorang menjadi lesbi mulai dari SD, SMP dan SMA. Alasan menjadi lesbi karena dari diri dan dari teman. Komunitas lesbi sangat tertutup tetapi kacuping-kacuping (anak baru gede) yang mulai terbuka.

Semua lesbi menggunakan obat dalam pergaulan di komunitas lesbinya .Obat yang digunakan lesbi yaitu Somadril dan Karnopen. Obat digunakan untuk menenangkan fikiran, menghilangkan stress, dijadikan sebagai simbol anak gaul. Efek saat menggunakan obat yaitu fly, dan stress hilang. Lesbi meminum obat 3 sampai 12 biji dengan Sprite atau Coca Cola, teh danmakan makanan yang pedas. Informasi obat didapat dari teman dan pasangan. Setelah menggunakan obat lesbi akan terbawa suasana hati, melakukan hubungan seks dan melakukan hal-hal yang tidak penting.

\section{SARAN}

- Bagi instansi yang terkait khususnya Dinas Kesehatan, perlu melakukan metode penyuluhan terhadap komunitas lesbi tentang penyalahgunaan obatobatan yang berada di kota Makassar.

- Pengawasan terhadap pembelian obatobat penenang di apotik-apotik kiranya lebih diperketat oleh pihak farmakologi bersama pihak berwajib.

- Bagi orang tua sebaiknya perlu menjadi sahabat bagi anak-anaknya agar tidak terjerumus masuk dalam perilaku 
beresiko dalam penyalahgunaan obatobatan, mengenal teman dan komunitas pergaulan anaknya agar dapat mengontrol disamping pondasi ilmuilmu agama yang lebih diperkuat.

\section{DAFTAR PUSTAKA}

Agustina dkk. (2005). Sетиa Tentang Lesbian. Ardhanary Institute, Jakarta Selatan

BangkaPos. (2011). ABG Simpan 900 Butir Obat diakses dari http://cetak.bangkapos.com/etalase/r ead/40030/ABG+Simpan+900+Butir +Obat+html pada tanggal 04 Juli 2011

Fethers, K., et al. (2011). Sexually transmitted infections and risk behaviours in women who have sex with women. diakses pada tanggal 13 Februari 2011

Hiwari, D. (2000). Manajemen Stress, Cemas dan Depresi. Jakarta: FKUI. diakses tanggal 03 Juli 2011

Ilyas, M. (2008). Analisis Faktor individu Penggunaan Napza di Kota Makassar. Skripsi: tidak diterbitkan. diakses pada tanggal 14 Februari 2011

Muctaromah, B. (2010). Tahapan Perkembangan Gay, Lesbian dan

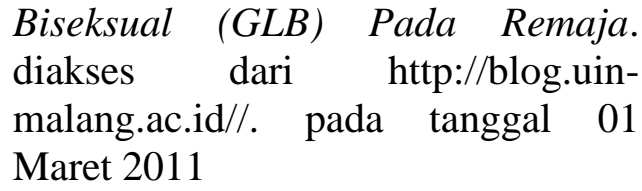

National Institute on Drug Abuse. (2002). Preventing Drug Use Among Children andAdolescents. 2nd Ed. Maryland : U.S Department Healt and Human Sevices - National Institute of Health. 2003. 1-25.

Notoatmodjo, S. (2007). Promosi Kesehatan dan Ilmu Perilaku. Jakarta; PT.Rineka Cipta

Puslitbang Farmasi. (1992). Obat yang Disalahgunakan oleh Pasien Ketergantungan Obat di Rumah Sakit Ketergantungan Obat dan Inabah. diakses pada tanggal 03 Juli 2011.

Torres, G. \& Horowitz. (1996). Individual and combined effect of etanol and cocain on mitracellular signal and gene expression. Prog-NeuropsychoPharmacol-Biol-Psichiary, 20 (4), 561-596.

UNODC. (2010). World Drug Report 2010. diakses dari http://www.unodc.org/documents/wd r/WDR_2010/World_Drug_Report_ 2010_lo-res.pdf pada tanggal 10 Maret 2011 